\title{
The Design, Construction and Operation of a 75 kW Two-Stage Gasifier
}

Henriksen, Ulrik Birk; Ahrenfeldt, Jesper; Jensen, Torben Kvist; Gøbel, Benny; Bentzen, Jens Dall; Hindsgaul, Claus; Sørensen, Lasse Holst

Published in:

The 16. International Conference of Efficiency, Cost, Optimization, Simulation, and Environmental Impact of Energy Systems, ECOS 2003

Publication date:

2003

Document Version

Early version, also known as pre-print

Link back to DTU Orbit

Citation (APA):

Henriksen, U. B., Ahrenfeldt, J., Jensen, T. K., Gøbel, B., Bentzen, J. D., Hindsgaul, C., \& Sørensen, L. H. (2003). The Design, Construction and Operation of a $75 \mathrm{~kW}$ Two-Stage Gasifier. In The 16. International Conference of Efficiency, Cost, Optimization, Simulation, and Environmental Impact of Energy Systems, ECOS 2003 (pp. 1081-1088). Technical University of Denmark.

\section{General rights}

Copyright and moral rights for the publications made accessible in the public portal are retained by the authors and/or other copyright owners and it is a condition of accessing publications that users recognise and abide by the legal requirements associated with these rights.

- Users may download and print one copy of any publication from the public portal for the purpose of private study or research.

- You may not further distribute the material or use it for any profit-making activity or commercial gain

- You may freely distribute the URL identifying the publication in the public portal 


\title{
The Design, Construction and Operation of a $75 \mathrm{~kW}$ Two-Stage Gasifier.
}

\author{
Ulrik Henriksen, Jesper Ahrenfeldt, Torben Kvist Jensen, Benny Gøbel, \#\#Jens Dall Bentzen, Claus \\ Hindsgaul, \#Lasse Holst Sørensen.
}

\author{
Biomass Gasification Group \\ Department of Mechanical Engineering \\ Technical University of Denmark \\ 2800 Kongens Lyngby \\ Denmark
}
\#ReaTech C/O CAT Post box 30
4000 Roskilde
Denmark

\#\#COWI

Parallelvej 15

2800 Kongens Lyngby

Denmark

\begin{abstract}
The Two-Stage Gasifier was operated for several weeks (465 hours) and of these 190 hours continuously. The gasifier is operated automatically unattended day and night, and only small adjustments of the feeding rate were necessary once or twice a day. The operation was successful, and the output as expected. The engine operated well on the produced gas, and no deposits were observed in the engine afterwards. The bag house filter was an excellent and well operating gas cleaning system. Small amounts of deposits consisting of salts and carbonates were observed in the hot gas heat exchangers. The top of the reactor had to be constructed in some other material.
\end{abstract}

Key words:

Gasification, low tar, Biomass, Engine, deposits, condensate

\section{Introduction}

Development of processes for thermal gasification of biomass has been going on for many years. One of the main problems has been the presence of tars in the produced gas. Tars damage internal combustion engines, gas turbines and other machinery. Therefore gas cleaning and reduction of the produced tar have been subject for lot research projects [1]. Gasification processes producing only very low amounts of tars will have great potential as tar treatments can be avoided [2].

At the Biomass Gasification Group, MEK, DTU the Two-stage gasification process have been developed during he last 14 years. The main advantages of the two-stage gasification process is, that contrary to most other gasifiers, very small amounts of tar is present in the produced gas. [3], [4].

During the years test runs of up to a few days duration of different pilot plants have been carried out with an army of engineers and scientists to operate, measure and control the operation.

During the years it has been attempted, without great success, to establish cooperation with companies for further development and commercialisation of the process. The problem has been that the pilot plant has only operated for 
100-200 hours, which was not enough to convince private investors of the reliability of this new technology.

Thus it was decided to build a small-scale demonstration plant for fully automatic operation for at least 1000 hours at DTU. The small scale (75 kW thermal) was chosen for economical reasons. It was decided to use wood chips as fuel. The gasifier called "Viking" (see figure 1) is a traditional two-stage gasifier which means that the pyrolysis and char gasification occur in separate reactors (see figure 2 ).

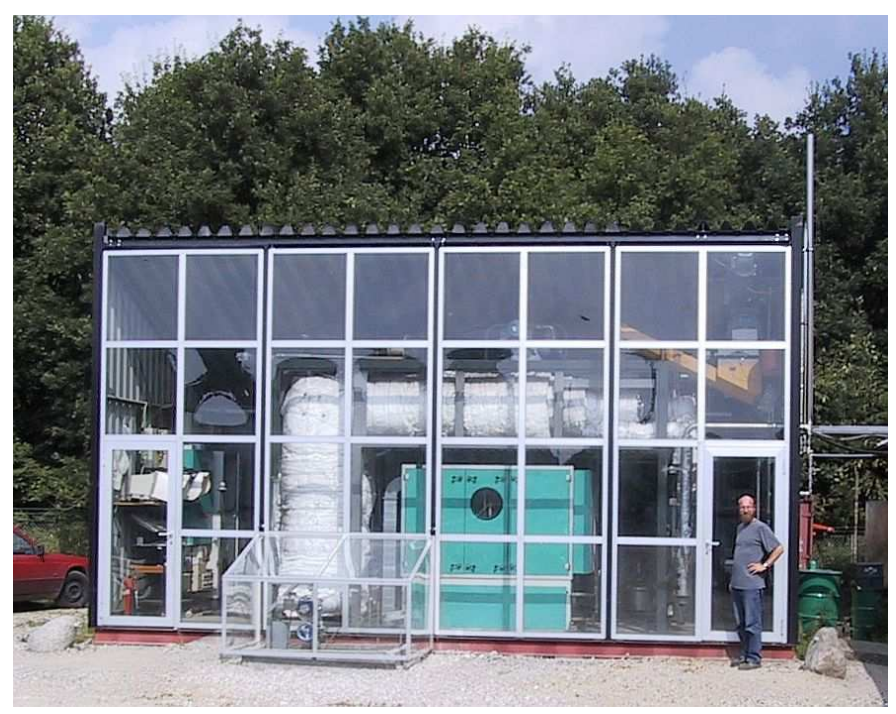

Figure 1. Picture of the Viking gasifier in operation.

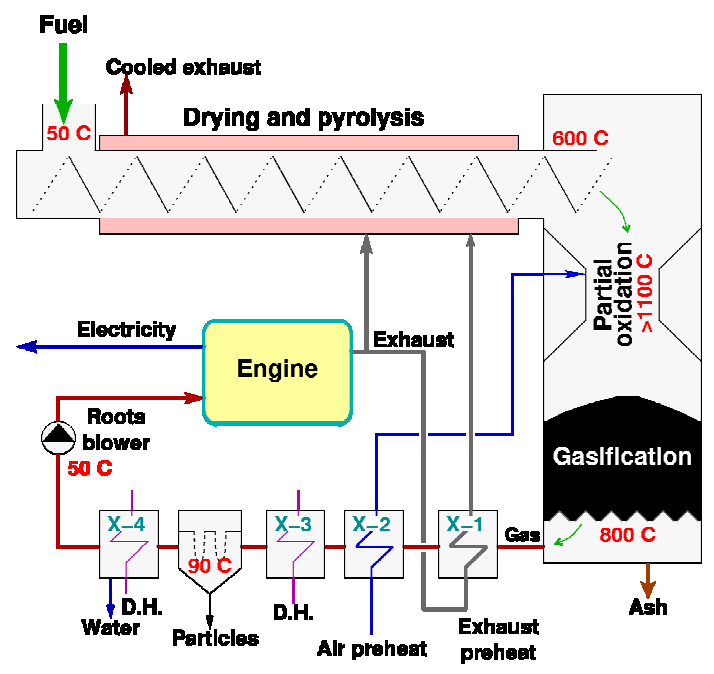

Figure 2. The Viking gasifier.
Between the pyrolysis and the gasification, the pyrolysis products are partially oxidised by air addition. Thus the tar contents in the volatiles are reduced by a factor of 100 and thermal energy for the endothermic char gasification is produced.

When the partially oxidised pyrolysis products pass through the char bed in the char gasification reactor, the tar contents are further reduced by a factor of 100 .

The resulting tar content in the produced gas is less then $15 \mathrm{mg}$ per $\mathrm{Nm}^{3}$ [5].

\section{The plant}

The plant consists of a number of main components, which will be described briefly in the following

Feeding system

A container with a conveyer in the bottom feed the wood chips to a screw conveyer. A loch hopper system (two valves separated by a screw conveyer) secures that no gas escapes the system. After this the wood chips are fed into a box where a screw conveyer feed the fuel to the pyrolysis unit. The speed of this screw controls the feeding rate. A little nitrogen was supplied to the box to avoid tar condensation in the feeding system.

\section{Pyrolysis unit}

The exhaust gas from the connected gas engine is used for external heating of the pyrolysis reactor. A screw conveyer leads the biomass through the pyrolysis reactor.

In the first part of the pyrolysis reactor the biomass is dried. In the second part the pyrolysis takes place. Pyrolysis demands higher temperatures than drying, and to satisfy this, the exhaust gas is split into two streams (se figure 2). One stream is heated further by heat exchanging with the hot producer gas, and the other is led directly to the pyrolysis unit where it joints the other stream.

\section{Char gasifier}

The gasification reactor is build with a metallic shell. In the top where the temperatures are the highest (up to $1270{ }^{\circ} \mathrm{C}$ ) and only gas is present, a ceramic composite construction based on ceramic fibres coated with aluminium oxides is used. 
In the char bed metal (253 MA) is in direct contact with the char. It provides a gastight reactor wall keeping the gas from bypassing the char bed, as this will result in increased tar amounts in the produced gas [6].

Geometrically the reactor is constructed as three concentric cylinders. In the bottom the cylinder meets a square grate.

Grate

The grate is a moving grate, see figure 3 .

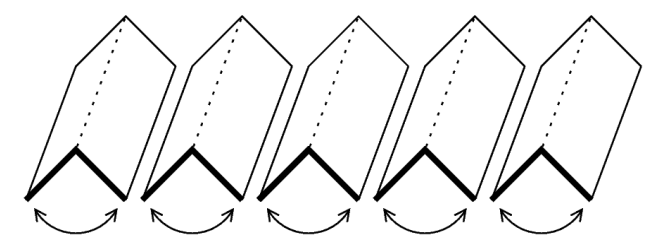

Figure 3. The grate.

When the grate is moved ash and char pass through causing the pressure drop over the char bed to decrease.

Grate movement is triggered when the pressure drop across the char bed in the char gasifier exceeds threshold typically $300 \mathrm{~mm} \mathrm{WG}$ ).

The ash is removed by two screw conveyers.

Gas system

The gas is heat exchanged with part of the exhaust gas. Then the gas is heat exchanged to pre-heat the air for the gasifier. Then it is cooled to just above the water dew point (about $90{ }^{\circ} \mathrm{C}$ ) and cleaned in a bag house filter. After the bag house filter a paper cartridge filter acts as a police filter. After this the gas is cooled further to about $50{ }^{\circ} \mathrm{C}$ and condensate is removed. To ensure that droplets produced during the condensation is removed the gas will then pass through another paper cartridge filter (similar the police filter) which acts as demister. The gas flow is driven by a roots blower, which is a volumetric machine. The blower is built from conventional steel.

Bag house filter.

The filter material in the bag house filter is ordinary polyethylene bags back flushed by nitrogen.
When the pressure drop exceeds $100 \mathrm{~mm}$ WG the back flush is initiated, reducing the pressure drop reduced to about $25 \mathrm{~mm} \mathrm{WG}$, see figure 8 .

Engine

The gas is feed to an engine. The engine is a natural aspirated cylinder DEUTZ spark ignition gas engine operating at full load. The engine is connected to producer gas and natural gas. Natural gas is used during the start op. It is possible to operate the engine on producer gas, natural gas and any mixture of the two. The produced electricity is supplied to the electric grid. The produced heat from cooling the produce gas cooling the exhaust gas and the cooling of the engine are supplied to a heat system in order to simulate a central heating system. The return temperature from the central heating system is kept constant.

Control

The gasifier is controlled by a Simens PLC. The overall control strategy is to produce a constant gas flow to the engine. In order to obtained this, the roots blower is operated at constant speed. The air addition is adjusted to give atmospheric pressure at the biomass fuel inlet in the pyrolysis unit.

The system is equipped with automatic security systems, and can operate unattended.

\section{Operation}

The gasifier had been started a few times before the 400 hours test. Each time different problems occurred, and were solved.

During the summer of 2002 the gasifier was in operation for 50 hours feeding with producer gas to the engine, and for 75 hours with wood chips to the gasifier. After this the gasifier was shut down before the holiday without any problems. After the holiday it was restarted. This resulted in a total of 465 hours of operation of these 410 hours with producer gas to the engine.

The fuel was woodchips from beach delivered from Junker Industries in Køge. An analysis of this wood is shown in table 1 .

The temperature of the return water in the heating system was constantly $40{ }^{\circ} \mathrm{C}$. 
The only essential parameter, which was not adjusted automatically, was the fuel-feeding rate. This was only adjusted manually once or twice a day as the process was quite stable.

\section{Results}

The efficiency of the system was as expected, about $25 \%$ from wood to electricity.

During this test there were some shut downs for different reasons. For long periods no problem occurred. The longest continuous running period was 190 hours. In figure 4 the gas flow during the full test is shown.

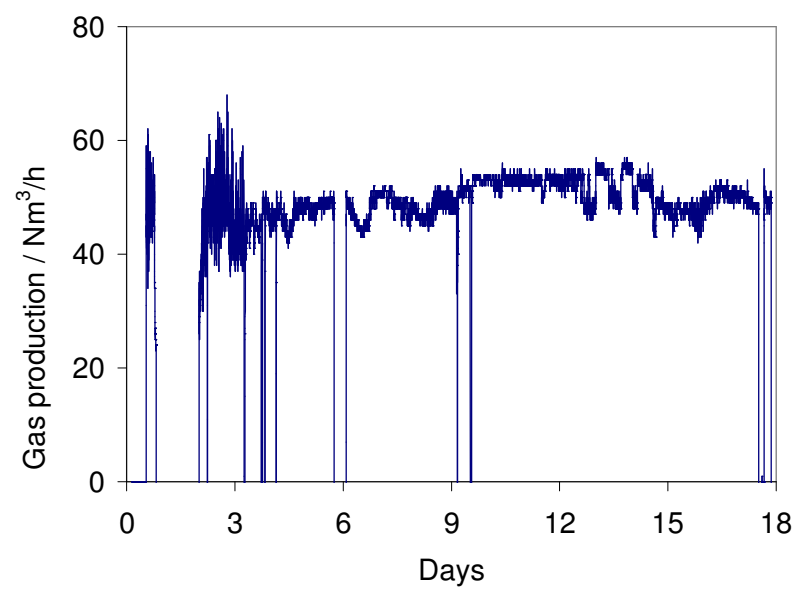

Figure 4. Gas flow development during the test period.

The gas composition was quite constant in spite of oscillations with a frequency equal to the rotation frequency of the screw conveyer in the pyrolysis unit. The reason is that char falls down in batches. These are heated up to gasification temperature and gas is released rapidly. This influences the gas composition.

In figure 5 an example of the gas composition development is shown for a 12-hour period.

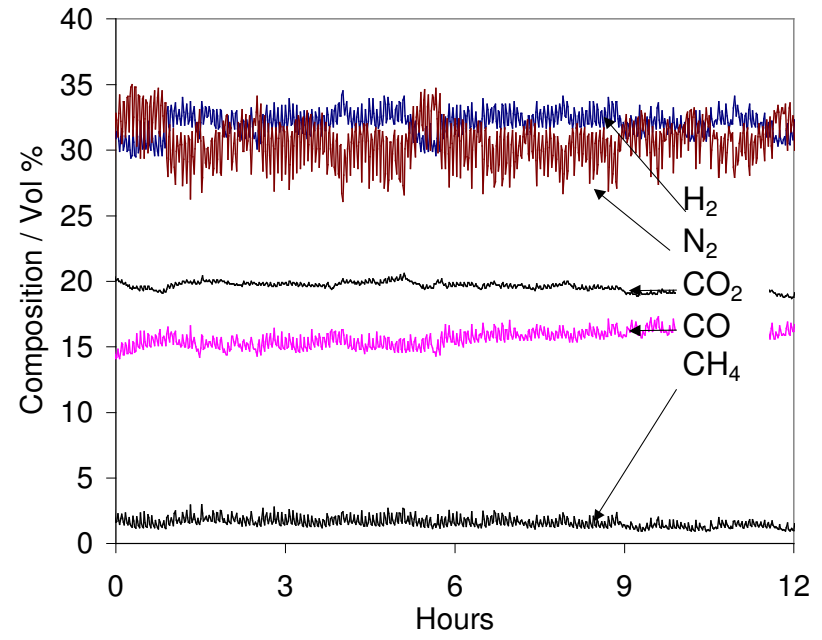

Figure 5. An example of the gas composition.

The specific heating values for a 12-hour period are shown in figure 6 .

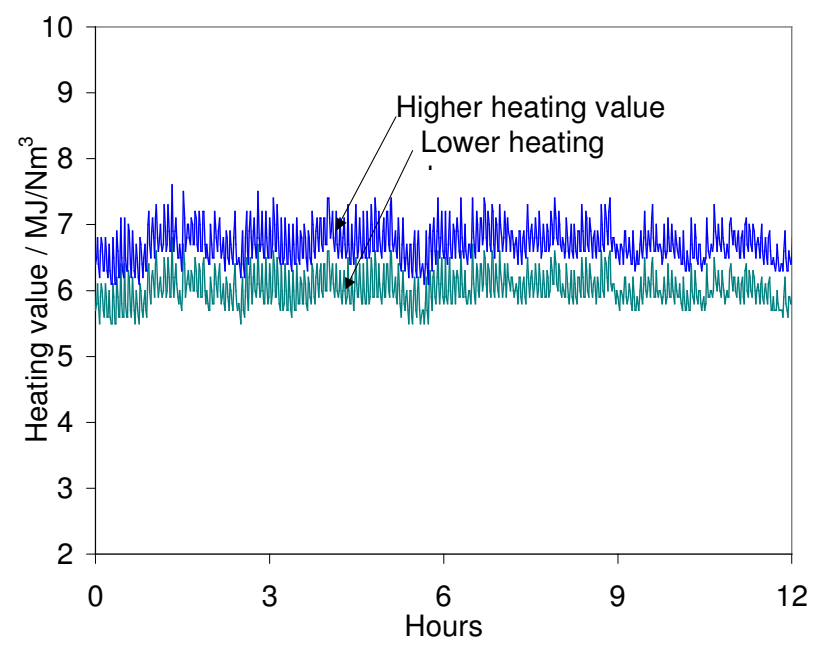

Figure 6. An example of specific heating values in the produced gas.

The temperature at the char outlet of the pyrolysis unit is around $600{ }^{\circ} \mathrm{C}$. The maximum operating temperature in the top of the gasifier is 1100-1200 ${ }^{\circ} \mathrm{C}$. At the grate and in the gas outlet the temperature is $725-800{ }^{\circ} \mathrm{C}$.

An example of the temperature development in the gasifier is shown in figure 7 . 


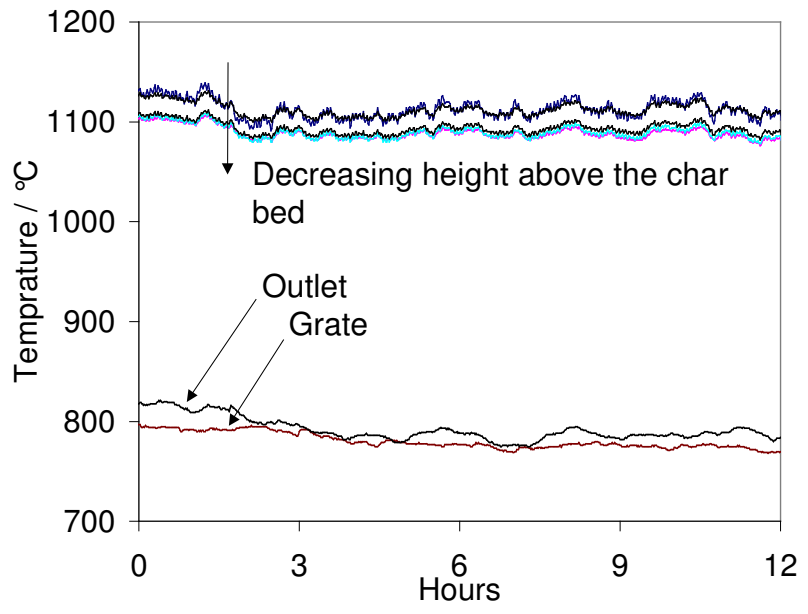

Figure 7. Example of temperatures in the gasifier.

The pressure drop development across the char bed is shown in figure 8. It is seen that the pressure drop is oscillating. This happen without activating the grate. It was concluded that the pressure drop across the char bed could stabilise without active removal of char and ashes from the bottom of the bed.

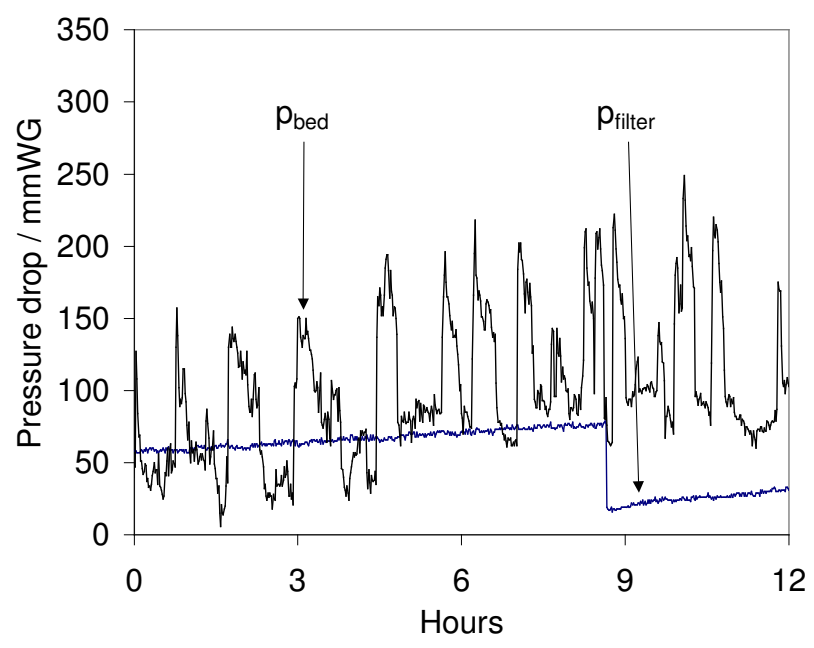

Figure 8. Pressure drop across the char bed and across the bag house filter.

Bag house filter

The operation of the bag house filter was successful. The gas speed through the filter material was about $0,2 \mathrm{~cm} / \mathrm{s}$.

Back flushing occurred about once a day and the result of one flush can be seen in figure 8 .
After 400 hours no permanent increase in pressure drop was seen.

The pressure drop across the police filter was constant (about $5 \mathrm{~mm} \mathrm{WG}$ ) during the whole test. This indicates a good cleaning efficiency of the bag house filter.

\section{Engine}

The engine was operated for 410 hours on producer gas. The engine was started up fuelled by natural gas, and switched to producer gas. The power was reduced compared to natural gas operation by a factor of 0.8 and the power output was about $15-20 \mathrm{~kW}$ electric. The efficiency from gas to mechanical power was about $28 \%$. The oxygen content in the exhaust gas from the engine varied from $0.5 \%$ to $6 \%$.

During the test occasional problems with the ignition system was observed. Sometimes one of the cylinders did not ignite for several rotations.

Pyrolysis reactor

The biomass and char transportation through the pyrolysis reactor is carried out by a screw conveyer, and thus, for every rotation a portion of char will fall into the gasifier.

This lead to an oscillating gas flow and gas composition as the temperature here is several hundred degrees higher than the pyrolysis temperature.

For water content in the fuel up to $45 \%$ wet basis the capacity of the pyrolysis reactor was sufficient.

Grate

During this test the grate was only moved once or twice. In all other situations the pressure drop did not exceed the upper limit ( $300 \mathrm{~mm} \mathrm{WG}$ ). The char lost with the ashes were about $0.5 \%$ of the supplied dry fuel, which is a very low fraction for this type of gasifier.

Feeding system

The feeding system worked well during the test with only one stop. A big peace of wood was blocking. The gas sealing from the gasifier to the surroundings was acceptable. 


\section{Inspection after 400 hours operation.}

After about 400 hours of operation (410 hours producer gas to the engine totally and 465 hours fuel fed into the gasifier) the system was stopped. The gasifier was opened and inspected

\section{Engine}

The tops of the three cylinders were removed for inspection.

The cylinder liner and the piston top as well as the engine top were covered with small deposits as seen after operation on pure natural gas. This producer gas gave no problem related to deposits. The spark plugs were unaffected.

\section{Gas system}

The gas tubing between the $90{ }^{\circ} \mathrm{C}$ gas cooler and the bag house filter were inspected. Carbon powder was found, but nothing was sticking to the tube wall.

After the bag house filter no visible dust was observed in the gas tubes.

The police filter was opened and no visible dust could be seen on the filter.

In the condenser and the demister condensate was seen. It looked like clean water but smelled like ammonia.

The roots blower was inspected, and it looked unaffected.

A small security filter in the gas tube before the engine had a little dark grey spot. This was not problematic.

The condensate from the gas cooler was analysed. The results were compared to results from earlier investigations of condensate from the $100 \mathrm{~kW}$ two-stage gasifiers [5] and good agreement with the older experiments was found, see Table 1. Ammonia and small amounts of naphthalene are seen. This condensate can be led directly to the public sewer system.

\begin{tabular}{|c|c|c|c|c|c|c|}
\hline & V1 & V2 & V3 & $\mathrm{V} 4$ & H1 & $\mathrm{H} 2$ \\
\hline Naphtalele $[\mu \mathrm{g} / 1]$ & 10 & 1 & 8 & 21 & 21 & 1 \\
\hline Anthracene $[\mu \mathrm{g} / \mathrm{l}]$ & $<2$ & $<2$ & $<2$ & $<2$ & $<0.3$ & $<0.3$ \\
\hline Pyrene $[\mu \mathrm{g} / \mathrm{l}]$ & $<1$ & $<1$ & $<1$ & $<1$ & $<0.3$ & $<0.3$ \\
\hline Flourene $[\mu \mathrm{g} / \mathrm{l}]$ & - & - & - & - & 0.3 & 0.5 \\
\hline Phenanthrene $[\mu \mathrm{g} / \mathrm{l}]$ & 0.5 & 0.5 & 2.1 & 1.2 & 1.9 & 3.1 \\
\hline Phenol[ $[\mu \mathrm{g} / \mathrm{l}]$ & $<10$ & 17 & $<10$ & $<10$ & $<1$ & $<1$ \\
\hline Guaiacol[ $[\mu \mathrm{g} / 1]$ & $<6$ & 8 & 11 & $<6$ & - & - \\
\hline Ammonia[g/l] & 0.8 & 1.26 & 0.96 & 0.96 & 1.4 & - \\
\hline
\end{tabular}

Table 1. V1-V4 are test with the Viking gasifier. $\mathrm{H} 1$ and $\mathrm{H} 2$ are tests carried out years ago with the $100 \mathrm{~kW}$ gasifier [7].

Feeding system.

No alarming corrosion or deposits observed.

Bottom of reactor

Below the grate the bottom of the gasifier was inspected. Black and white deposits were seen here. No corrosion was observed.

Grate

On the grate a lot of big lumps of grey ashes were found.

This was obviously not removed during operation, which is understandable as the grate was only activated a few times.

These lumps could not be removed through the grate, and would soon or later result in operation stop.

\section{Char gasifier}

On the metal shell in the lower part of the reactor ash deposits were found.

Surface corrosion was observed on this shell.

Further up in the reactor corrosion on the metal shell was seen as well. Here some iron scales were observed.

In the top the reactor, the fibre ceramic construction was seriously damaged.

Near the air valves even the metallic shell was damaged.

This part of the reactor had to be replaced before further operation.

Hot heat exchanger

The hot heat exchangers cool the gas from about $800^{\circ} \mathrm{C}$ to about $450^{\circ} \mathrm{C}$ 
The hot heat exchanger inlet was opened. Small but significant amounts of hard deposits sticked to the bottom of the exchanger tubes. Two deposit samples were collected for SEM-EDS analysis. In table 2 the composition of the two samples are shown together with the composition of the wood chips ash.

The inorganic composition of the wood chips was determined according to ISO 9411:1 by dkTeknik (Denmark). The wood sample is rich in $\mathrm{Ca}, \mathrm{K}$ and in particular $\mathrm{Na}$ and $\mathrm{Cl}$. The content of $\mathrm{Si}$ is relatively low.

Compared to the raw wood sample the deposits are in particular enriched in $\mathrm{Na}$ and $\mathrm{C}$ and fairly depleted in $\mathrm{Ca}, \mathrm{Mg}, \mathrm{S}, \mathrm{Cl}$ and $\mathrm{P}$.

\begin{tabular}{|c|c|c|c|}
\hline $\begin{array}{c}\text { Mass } \\
\%\end{array}$ & $\begin{array}{c}\text { Deposit } \\
\text { sample 1 }\end{array}$ & $\begin{array}{c}\text { Deposit } \\
\text { sample 2 }\end{array}$ & $\begin{array}{c}\text { Wood chips } \\
\text { Ash (oxides) }\end{array}$ \\
\hline $\mathrm{Si}$ & 4.8 & 2.7 & 2.7 \\
\hline $\mathrm{Al}$ & 0.2 & 0.1 & 0.2 \\
\hline $\mathrm{Fe}$ & 3.1 & 2.2 & 0.2 \\
\hline $\mathrm{Mn}$ & 0.4 & - & - \\
\hline $\mathrm{Mg}$ & 0.3 & 0.1 & 3.4 \\
\hline $\mathrm{Ca}$ & 4.8 & 0.9 & 30.0 \\
\hline $\mathrm{Na}$ & 8.2 & 19.9 & 4.9 \\
\hline $\mathrm{K}$ & 13.4 & 3.4 & 9.6 \\
\hline $\mathrm{S}$ & 0.3 & 0.2 & 2.1 \\
\hline $\mathrm{P}$ & 0.4 & 0.2 & 1.1 \\
\hline $\mathrm{Cl}$ & 1.1 & 0.2 & 7.0 \\
\hline $\mathrm{Ba}$ & 1.2 & - & - \\
\hline $\mathrm{C}$ & 12.8 & 10.9 & - \\
\hline $\mathrm{O}$ & 49.3 & 59.1 & 48.8 \\
\hline
\end{tabular}

Table 2. EDS -analysis of Deposits from the bottom of the hot heat exchanger tube.

The deposits samples were ash with a low carbon content. The high $\mathrm{Na}$ and $\mathrm{K}$ content suggest that the carbon, $\mathrm{K}$ and $\mathrm{Na}$ are primarily bound in the form of a molten and water-soluble $\mathrm{Na}$ and $\mathrm{K}$ carbonate -salt fraction, where the expected mass ratio of $\mathrm{C} / \mathrm{O}=12 / 48$. Equilibrium calculations suggest that this salt melt in dependence of the formation temperature also contains small amounts of alkali chlorides. Embedded in the carbonate salt melt we also suggest that solids like potassium calcium carbonates are present as well as calcium silicate and magnesium calcium silicate and iron calcium silicate compounds. The high depletion of calcium in the deposits indicates the absence of liquid potassium calcium carbonate melt- formation at around $800^{\circ} \mathrm{C}$.

Medium temperature heat exchanger

This heat exchanger cools the gas from about 450 ${ }^{\circ} \mathrm{C}$ to about $90^{\circ} \mathrm{C}$.

In this heat exchanger only tiny amounts of deposits were seen. They were powder like and loose.

\section{Conclusion}

It was demonstrated that the two-stage gasifier can be operated for several weeks (465 hours) of these 190 hours continuously.

The gasifier was operated automatically day and night, and only small adjustments of the feeding rate were necessary once or twice a day.

The operation was successful, and the output as expected.

The engine operated well on the produced gas, and no deposits were seen in the engine afterwards. Small amounts of deposits were observed in the hot heat exchangers.

The bag house filter was an excellent well operating gas cleaning system for this gosifyer.

The top of the reactor has to be constructed in some other material.

\section{Later developments}

A new top of the reactor has been constructed. Totally more then 1000 hours of operation are now achieved.

Detailed measurements will be carried out.

\section{Acknowledgement}

The Danish Ministry of Energy supported this work.

\section{References}

[1] T.A. Milne, N. Abatzoglou, R.J.Evans, Biomass Gasifier "Tars": Their Nature, Formation, and conversion. NREL/TP-570255357 National Renewable Energy Laboratory Colorado, USA November 1998. 
[2] Lopamudra Devi, Krzysztof J. Ptasinski, Frans J.J.G.Janssen A review of the primary measures for tar elimination in biomass gasification processes Biomass \& Bioenergy 24 (2003) pp.125-140

[3] Ulrik Henriksen, Erik Kofoed, Søren Gabriel, Thomas Koch, Ole Christensen. Gasification of Straw. In proceedings of the conference: "6th E. C. Conference. Biomass for Energy, Industry and Environment ". Athens. Greece. April 1991. Pp. 797 - 801.

[4] Ulrik Henriksen, Ole Christensen. Gasification of Straw in a Two-Stage $50 \mathrm{~kW}$ Gasifier. In proceedings of the conference: "8th European Biomass Conference. Biomass for Energy, Environment, Agriculture and Industry". Vienna, Austria. October 1994. Vol. 2. Pp. 1568 -1578.

[5] Peder Brandt, Elfinn Larsen, Ulrik Henriksen.

High Tar Reduction in a Two-Stage Gasifier. Article in: Energy and Fuels. Vol. 14, Issue 4. 2000. pp. 816-819.

[6] Jens Dall Bentzen, Ulrik Henriksen, Claus Hindsgaul, Peder Brandt. Optimized TwoStage Gasifier. Proceedings of 1st World Conference on Biomass for Energy and Industry, Sevilla, Spain, June 5-9 2000, London, James \& James (Science Publishers) Ltd.

[7] Jens Dall Bentzen, Ulrik Henriksen, Claus Hindsgaul. Condensate from a Two-Stage Gasifier. Proceedings of 1st World Conference on Biomass for Energy and Industry, Sevilla, Spain, June 5-9 2000, London, James \& James (Science Publishers) Ltd. 